\title{
Model-Model Pendidikan Perdamaian Bagi Anak Dalam Konteks Gereja
}

\section{Models of Peace Education for Children in the Context of the Church}

\author{
Tirsa Budiarti ${ }^{1)^{*}}$ \\ ${ }^{1)}$ Dosen Sekolah Tinggi Teologi Moriah \\ *)Penulis korespondensi: ichaarti77@gmail.com
}

Received: 15 January 2018/Revised: 7 February 2018 /Accepted: 18 March 2018

\begin{abstract}
Abstrak
Tulisan ini bertujuan untuk mendeskripsikan dan menganalisis model-model pendidikan perdamaian bagi anak dalam konteks gereja. Tulisan ini dimotivasi oleh maraknya tindakan kekerasan dalam berbagai relasi, baik dalam ranah domestik maupun publik yang ada di Indonesia, sehingga menyebabkan membudayanya kekerasan. Tulisan ini membuktikan bahwa pendidikan perdamaian adalah suatu upaya jangka panjang yang efektif yang dapat menjadi budaya tandingan bagi budaya kekerasan tersebut. Pendidikan perdamaian dapat dilaksanakan lebih maksimal apabila ditanamkan sejak dini dalam diri anak-anak dan dalam konteks gereja, karena bersama dengan gereja, anak-anak turut mengemban misi perdamaian demi terwujudnya Kerajaan Allah. Penulis juga menemukan bahwa pendidikan perdamaian perlu dilakukan dalam tiga tahap, yaitu tahap penyadaran melalui model kontemplatif dan model problemposing, tahap penghayatan melalui model integrasi (dengan kalender gerejawi) dan model bermain peran, serta tahap penerapan melalui model aksi-refleksi. Penelitian lanjutan yang berkaitan dengan aplikasi model-model tersebut dalam konteks gereja lokal di Indonesia sangat direkomendasikan.

Kata Kunci: Model pendidikan perdamaian, anak, gereja

This writing aims to describe and analyze models of peace education for children in the context of the church. This writing is motivated by the emergent acts of violence in various relationships both in the domestic and public sphere in Indonesia, which is causing violence to become culture. This writing proves that peace education is an effective long-term effort, which can be a counter-culture for the violence culture. Peace education can be done more optimally if it is planted early on in the lives of children and in the context of the church, because together with the church, children are also held responsible in taking the mission of peace for the spreading of the kingdom of God. The author also found that peace education needs to be done in three stages: the awareness stage through contemplative model and problem-posing model; the stage of affection through the integration model (with ecclesiastical calendar) and role playing model; then the implementation stage through the action-reflection model. Further research linking the application of these models in the context of local churches in Indonesia is strongly recommended.
\end{abstract}

Key Words: Models of peace education, children, church 


\section{Pendahuluan}

Kekerasan telah menjadi budaya dalam kehidupan masyarakat pada masa kini. Kekerasan bahkan telah menjadi roh dari dunia modern yang melanda seluruh dunia. ${ }^{1}$ Kekerasan muncul dalam berbagai bentuk seiring perkembangan zaman. Berita, video, gambar, acara hiburan, olahraga, bahkan permainan anak-anak banyak mengangkat tema kekerasan dan membawa dampak negatif dalam kehidupan masyarakat. Meskipun demikian, kekerasan dianggap hal biasa karena masyarakat telah terbiasa melihatnya. Banyak orang bahkan bisa membenarkan tindakan kekerasan tertentu karena memiliki tujuan dan alibi-alibi yang dianggap baik. Hal semacam ini memberi tempat bagi kekerasan untuk berkembang dan dapat melegitimasi pandangan yang menyatakan bahwa kekerasan diperlukan.

Dalam konteks Indonesia, awalnya kekerasan banyak dijumpai dalam kehidupan rumah tangga, lembaga pendidikan, tempat kerja, bahkan dalam hidup bermasyarakat melalui konflik-konflik sosial. Kerusuhan-kerusuhan yang terjadi di Ambon, Poso, Papua dan beberapa tempat lain cukup menyita perhatian masyarakat. Konflik yang terjadi biasanya dilatarbelakangi oleh perbedaan suku, ras, kepentingan, kesenjangan ekonomi, bahkan ada banyak konflik bernuansa agama berakhir dengan suatu tindakan anarkis yang merenggut nyawa.

Agama memang memiliki beberapa fungsi. Di satu sisi, agama berfungsi sebagai tuntunan moral. ${ }^{2}$ Setiap orang yang memeluk agama apapun akan diajarkan tentang nilai-nilai hidup yang baik dan harus hidup sesuai dengan aturan-aturan yang dipercaya berasal dari Tuhan, sehingga dapat menuntun dalam suatu kehidupan yang lebih harmonis. Di sisi lain, agama berfungsi sebagai pemberi identitas kepada anggotanya. ${ }^{3}$ Fungsi kedua inilah yang cukup berpotensi menyebabkan konflik, karena identitas dapat memisahkan satu kelompok dengan kelompok yang lain. Iklim atau suasana yang timbul ketika kelompokkelompok agama tersebut bertemu salah satunya adalah persaingan, terutama jika berkaitan dengan paham dan cara yang paling benar untuk mengetahui Tuhan dan kehendak-Nya. Pada akhirnya, semuanya akan memicu sikap bermusuhan. Dengan demikian ada kesan yang kuat bahwa agama seolah tidak mendukung suatu kehidupan yang damai, namun justru menjadi pemicu konflik, bahkan konflik yang diwarnai kekerasan.

${ }^{1}$ Daniel Nuhamara, "Sistem Dominasi dan Resistensi Terhadapnya dalam Usaha Berteologi Sosial," Jurnal Studi Pembangunan Interdisiplin, vol. XX (2009):277.

${ }^{2}$ Emile Durkheim, The Elementary Forms of The Religious Life (New York: The Free Press, 1915), 464.

${ }^{3}$ Daniel Nuhamara, Pembimbing PAK (Bandung: Jurnal Info Media, 2007), 51. 
Akhir-akhir ini kekerasan banyak ditemukan dalam dunia maya. Masyarakat Indonesia tidak lagi berperang secara nyata. Banyak orang secara terbuka berperang melalui media sosial. Mereka berlomba-lomba membuat pernyataan, yang kadangkala diikuti dengan gambar-gambar seperti meme, yang bertujuan merundung (bullying) orang atau kelompok lain, baik yang berbeda pandangan, kelompok sosial, kepentingan, dan keyakinan. Kebebasan berpendapat dan berekspresi seringkali disertai dengan kekerasan yang merupakan suatu tindakan amoral, yang tidak mencerminkan kepribadian bangsa. Meskipun tidak melakukan kekerasan secara fisik, namun kekerasan semacam ini juga membawa dampak yang bersifat destruktif dan memecahbelah kehidupan bangsa.

Kekerasan, apapun bentuknya, biasanya mampu membuat korbannya mengalami trauma yang sulit disembuhkan. Tidak menutup kemungkinan trauma itu dapat memengaruhi kondisi psikis para korban, sehingga memicu mereka melakukan tindakan kekerasan lainnya. Akibatnya, kekerasan menjadi sebuah lingkaran setan yang membelenggu kehidupan manusia. Oleh sebab itu, perlu dipikirkan cara-cara untuk mengatasinya.

Banyak usulan yang telah dilakukan untuk mengatasi konflik yang berujung kekerasan dan budaya kekerasan itu sendiri. Misalnya, pemerintah berupaya melakukan mediasi dan menindak para pelaku kekerasan. Tidak hanya itu, masing-masing agama juga telah berusaha mengatasinya dengan dialog dan konseling. Menurut hemat penulis, hal tersebut adalah upaya jangka pendek, sehingga sewaktu-waktu tindakan kekerasan dapat terjadi kembali. Dalam hal ini, penulis mencoba untuk mencari sebuah upaya jangka panjang yang tidak sekedar menyembuhkan atau memulihkan keadaan, namun juga mencegah agar hal tersebut tidak terulang pada generasi selanjutnya. Usulan jangka panjang yang cukup potensial dan yang juga gencar dipromosikan oleh lembaga internasional seperti UNESCO dan UNICEF adalah melaksanakan pendidikan perdamaian. Pendidikan perdamaian berpotensi menciptakan suatu budaya damai yang akan menjadi budaya tandingan bagi budaya kekerasan.

Pendidikan perdamaian memang belum banyak dirasakan pengaruhnya di Indonesia. Tidak banyak tulisan atau buku-buku dalam bahasa Indonesia yang membahas tentang pendidikan perdamaian. Pendidikan perdamaian sepertinya masih merupakan sebuah konsep yang abstrak. Kedalaman dan keluasan dari substansi pendidikan perdamaian, seperti definisi, pokok kajian, metode, konteks, subjek pembelajar, dan sebagainya membuatnya menjadi semakin kompleks. Banyak yang belum memahami bagaimana seharusnya pendidikan perdamaian dilaksanakan, siapa yang paling efektif mempelajari pendidikan perdamaian, dan dalam konteks apa. Tulisan ini berusaha mengkonkretkan hal-hal tersebut. Oleh 
sebab itu, penulis hendak mendeskripsikan dan menganalisis modelmodel pendidikan perdamaian bagi anak dalam konteks gereja. Penulis menggunakan berbagai sumber bacaan seperti buku, jurnal, maupun artikel-artikel dalam website untuk menghasilkan kajian teoritis tentang model-model pendidikan perdamaian bagi anak dalam konteks gereja tersebut.

\section{Pengertian Pendidikan Perdamaian}

Pada dasarnya konflik adalah hal yang hampir tidak dapat dihindari. "Kata "perdamaian" merujuk bukan hanya pada suatu kondisi ketiadaaan konflik." ${ }^{4}$ Konflik adalah sebuah fakta hidup sehari-hari yang melanda berbagai hubungan, mulai dari hubungan internal yaitu di dalam diri sendiri, antarpribadi, antarkelompok di aras lokal sampai kepada internasional. Perdamaian sendiri merupakan suatu pertemuan unik dengan konflik karena perdamaian merupakan suatu proses untuk menyelesaikan konflik secara harmonis.

Galtung memaknai kata "perdamaian" dalam kaitannya dengan struktur sosial dan budaya sebagai perdamaian positif dan perdamaian negatif. ${ }^{5}$ Ada situasi atau kondisi tertentu yang menyebabkan perdamaian dapat disebut positif atau negatif. Menurut Galtung, perdamaian negatif adalah damai yang dipaksakan selama tidak ada kekerasan, seperti gencatan senjata, hidup terpisah, serta menjalin sebuah relasi yang tidak acuh satu dengan yang lain, sedangkan perdamaian positif berarti hadirnya keselarasan atau keharmonisan, keadilan secara struktural, sebagaimana makna damai yang sesungguhnya. ${ }^{6}$ Pernyataan Galtung pada dasarnya menjadi hal yang cukup penting karena memberikan gambaran yang mendasar, bahwa perdamaian tidak selamanya dimaknai sebagaimana makna yang sesungguhnya. Menurut hemat penulis, pendidikan perdamaian bertujuan untuk menciptakan perdamaian positif yakni sebagai suatu upaya pemberian keterampilan untuk mencegah konflik dan kekerasan melalui usaha merubah atau menciptakan tatanan sosial yang lebih adil, menyelesaikan akar masalah bukan hanya kulitnya, serta menciptakan suatu kehidupan damai secara nyata. Apabila terjadi

\footnotetext{
${ }^{4}$ Kathleen dan James McGinnis, Parenting for Peace and Justice (New York: Orbis Books, 1982), 23.

${ }^{5}$ Temesgen Tilahun, "Johan Galtung's Concept of Positive and Negative Peace in the Contemporary Ethiopia: An Appraisal," Academic Research Journal 3, no. 6 (Juni 2015):252.

${ }^{6}$ Baljit Singh Grewal, "Johan Galtung: Positive and Negative Peace," (Agustus 2003), diakses 1 November 2017, http://www.activeforpeace.org/no/fred/Positive_Negative_Peace.pdf.
} 
konflik, perdamaian akan menjadi transformator bagi konflik untuk menciptakan tatanan baru yang lebih baik bagi semua.

Menurut Page, pendidikan perdamaian adalah suatu usaha untuk menumbuhkan prinsip dan komitmen, serta usaha untuk membekali peserta didik dengan pengetahuan, nilai, sikap, yang dapat mewujudkan perdamaian, sehingga mereka layak disebut sebagai agen-agen perdamaian. ${ }^{7}$ Ada dua poin penting yang ditekankan Page, yakni usaha menumbuhkan komitmen untuk senantiasa hidup dengan damai dan pemberian informasi tentang berbagai pengetahuan yang dapat menjadi bekal bagi para agen perdamaian.

Dalam rangka menumbuhkan komitmen, pendidikan perdamaian dapat dipahami sebagai usaha untuk menanamkan, menumbuhkan, dan menyosialisasikan rasa cinta akan kedamaian, karena komitmen dapat terjadi apabila telah melalui suatu proses internalisasi terlebih dahulu. ${ }^{8}$ Sementara itu, pemberian informasi yang lengkap tentang hal-hal yang berkaitan dengan perdamaian juga penting untuk mencegah terjadinya berbagai aksi kekerasan. Informasi tersebut tidak saja berkaitan dengan hal-hal yang mendukung terciptanya perdamaian, tetapi juga hal-hal yang menyebabkan kondisi menjadi tidak damai berserta dampak-dampaknya. Peserta didik perlu dibekali berbagai informasi tentang konsekuensi dari perang, dampak dari ketidakadilan sosial, esensi serta nilai-nilai perdamaian, bentuk struktur sosial yang adil, cara-cara membangun struktur sosial yang baik, penanaman rasa cinta kepada dunia, keinginan untuk memiliki masa depan yang damai, dan kepedulian terhadap sesama. Selain itu, mereka perlu diberi tempat untuk mempraktikan apa yang telah mereka pelajari dan ketahui. Apabila kekerasan dan perdamaian dapat diidentifikasikan secara utuh, mulai dari gejala sampai kepada dampaknya, maka mereka akan memiliki kesadaran tentang baik dan mulianya hidup dalam suasana damai. Mereka memiliki gambaran yang sempurna mengenai perdamaian dan potensi-potensi yang dimilikinya, sehingga akhirnya mampu mengambil sikap untuk terus menyuarakan perdamaian. Melalui pendidikan perdamaian, terwujudnya perdamaian adalah suatu keniscayaan.

\footnotetext{
7 James S. Page, Peace Education: Exploring Ethical and Philosophical Foundations (USA: Information Age Publisher, 2008), 189.

${ }^{8}$ Berdasarkan Kamus Besar Bahasa Indonesia, internalisasi merupakan proses penghayatan terhadap suatu ajaran, doktrin, atau nilai. Dalam hal ini, penulis mengartikan internalisasi sebagai suatu proses akhir dari sosialisasi di mana seseorang (agen perdamaian) mengambil suatu ajaran, doktrin, atau nilai (dalam hal ini hal atau nilai-nilai perdamaian) sebagai suatu identitas atau jati diri sehingga telah mendarah daging (menyatu) dan menjadi bagian yang tidak dapat dipisahkan dari dirinya.
} 
Menurut hemat penulis, para agen perdamaian juga perlu mengkaji peran dan fungsi agama sebagai salah satu lembaga dalam masyarakat yang memperjuangkan perdamaian. Semua agama pada dasarnya mengajarkan kebaikan, karena itu perdamaian juga menjadi salah satu misinya. Meski identitas membedakan dan membatasi ruang lingkupnya, bukan berarti hal itu dapat dijadikan dasar untuk membatasi perdamaian pada kelompoknya saja. Dengan demikian, setiap pemeluk agama akan menyadari pentingnya mendefinisikan diri sebagai pembawa damai atau sebagai agen perdamaian di tengah dunia.

Harris dan Synott juga mencoba merumuskan pengertian pendidikan perdamaian sebagai seperangkat pembelajaran yang disusun dengan tujuan untuk membangkitkan keinginan dan kerinduan seseorang akan perdamaian, yang mana melaluinya seseorang akan dibimbing untuk menyelesaikan konflik dengan cara-cara damai, dibekali dengan keterampilan untuk melakukan analisis kritis terhadap ketetapan struktural yang memproduksi dan melegitimasi ketidakadilan. ${ }^{9}$ Beberapa unsur yang penting bagi pelaksanaan pendidikan perdamaian menurut pendapat Harris dan Synott yaitu, pertama, pendidikan perdamaian berupaya untuk membangkitkan kerinduan seseorang agar tetap menjaga kedamaian dalam berbagai situasi. Hal ini berarti pendidikan perdamaian adalah salah satu usaha untuk menumbuhkan kesadaran tentang berharganya kondisi yang damai itu sehingga secara sadar berusaha mewujudkannya. Kedua, pendidikan perdamaian merupakan usaha mengelola konflik dengan pilihan tanpa kekerasan. Hal ini menunjukkan bahwa hidup tanpa kekerasan merupakan sebuah pilihan. Sebesar apapun konflik yang terjadi, penyelesaian dengan cara damai harus lebih diutamakan. Dalam hal ini, pendidikan perdamaian mengembangkan kemampuan berpikir kritis seseorang sehingga mampu mencari solusi tanpa kekerasan. Ketiga, pendidikan perdamaian memberikan kemampuan untuk melakukan analisis kritis terhadap ketetapanketetapan struktural yang memproduksi dan melegitimasi ketidakadilan dan ketidaksetaraan hak. Dengan kata lain, pendidikan perdamaian meliputi analisis-analisis kritis terhadap sistem, aturan, dan struktur yang tidak adil. Hal itu tentu dapat menghambat terciptanya perdamaian, karena pada akhirnya tidak ada perdamaian dapat dibangun tanpa keadilan.

UNICEF sebagai salah satu lembaga yang memberi perhatian kepada anak-anak di seluruh dunia, turut serta memperkenalkan pendidikan perdamaian sebagai berikut:

${ }^{9}$ Ian Harris dan John Synott, "Peace Education for a New Century", Social Alternatives 21, no. 1 (2002):3-6. 
Peace Education in UNICEF refers to the process of promoting the knowledge, skills, attitudes and values needed to bring about behavior changes that will enable children, youth and adults to prevent conflict and violence, both overt and structural; to resolve conflict peacefully; and to create the conditions conducive to peace, whether at an intrapersonal, interpersonal, intergroup, national or international level. ${ }^{10}$

Beberapa unsur yang penting dari definisi UNICEF menurut penulis yaitu, pertama, pencegahan konflik dan kekerasan, termasuk yang bersifat struktural. Ada kecenderungan manusia untuk berkonflik dan melakukan kekerasan baik dalam lingkup individu, bahkan ketika berada dalam suatu struktur lembaga karena adanya perbedaan kepentingan. Dalam hal ini, UNICEF melihat pendidikan perdamaian sebagai upaya pencegahan, di mana setiap peserta didiknya diharapkan mampu menekan keinginan, kepentingan, dan keegoisan sehingga dapat berelasi dengan baik sebagai bagian dari masyarakat dan menempatkan kekuasaan sebagai sarana pemberdayaan dan bukan penindasan, sehingga konflik dan perang dapat dihindari. Unsur yang kedua yaitu penyelesaian masalah secara damai. Hal ini dilakukan ketika konflik tidak dapat dicegah. Pendidikan perdamaian hadir untuk memberikan solusi agar konflik yang terjadi tidak meluas dan menjadi anarkis, melainkan dapat diselesaikan dengan cara damai. Unsur yang ketiga adalah menciptakan suasana damai yang kondusif. Unsur yang ketiga ini mencakup usaha untuk membangun dan mempertahankan suasana damai (peace building), sehingga setiap relasi baik pribadi, antarpribadi, antarkelompok, nasional dan internasional ditemukan kedamaian.

Pengertian-pengertian tentang pendidikan perdamaian yang telah dipaparkan sebelumnya menunjukkan bahwa pendidikan perdamaian lebih difokuskan terhadap pencegahan dan penyelesaian konflik-konflik yang sering terjadi dalam kaitannya dengan relasi manusia. Penulis belum menemukan suatu pengertian yang juga memperhatikan perdamaian dalam kaitannya dengan lingkungan. Menurut penulis, kondisi alam yang semakin memprihatinkan serta banyaknya fenomena-fenomena alam yang mendatangkan musibah bagi kehidupan manusia, membuat penulis perlu menambahkan suatu unsur yang juga penting dalam pelaksanaan pendidikan perdamaian, yaitu perbaikan dan pemulihan lingkungan sebagai upaya melakukan pendidikan perdamaian secara global. Pendidikan perdamaian secara global berarti tidak saja mencakup relasi antarmanusia tetapi juga dengan alam semesta. Dengan demikian,

\footnotetext{
${ }^{10}$ Susan Fountain, "Peace Education in UNICEF", Working Paper of UNICEF New York (June 1999):1, diakses 28 Agustus 2017,

http://www.unicef.org/education/files/PeaceEducation.pdf.
} 
pendidikan perdamaian juga dapat berfungsi untuk menjaga stabilitas alam lingkungan.

Pada akhirnya penulis menyimpulkan bahwa pendidikan perdamaian adalah suatu proses pembelajaran yang cukup kompleks dan menyeluruh untuk menanamkan, menumbuhkan, serta mengembangkan rasa cinta akan kedamaian, melalui berbagai upaya seperti pengajaran, pemberian keterampilan, terutama dalam mengidentifikasikan hal-hal yang menunjang dan menghambat perdamaian, analisis kritis, dan penyelesaian konflik sosial tanpa kekerasan, serta pembentukan sikap, baik untuk masalah-masalah kemanusiaan maupun dalam kaitannya dengan alam. Pendidikan perdamaian disebut kompleks karena mencakup berbagai hal, mulai dari penumbuhan komitmen dan penanaman rasa cinta akan kedamaian sampai kepada analisis kritis dan penyelesaian konflik dengan cara damai. Pendidikan perdamaian disebut menyeluruh karena tidak hanya meliputi masalah relasi antarmanusia, tetapi juga masalah relasi manusia dengan lingkungan, serta mencakup tidak hanya hal-hal kognitif yang mencoba membuka wawasan dan pengetahuan peserta didik terutama yang berkaitan dengan hal-hal filosofis seperti nilai-nilai keadilan dan antikekerasan tetapi juga afektif, yakni dengan menumbuhkan perasaan cinta, kedambaan dan komitmen untuk hidup dalam damai, serta psikomotorik, yang ditandai dengan perubahan perilaku yang menjunjung tinggi perdamaian.

\section{Anak sebagai Subjek Pembelajar dalam Pendidikan Perdamaian}

Secara teologis, peserta didik mempunyai hak yang melekat dalam dirinya untuk diperlakukan dengan penghargaan karena mereka adalah ciptaan yang telah dimerdekakan oleh Tuhan, karenanya mereka adalah individu yang memiliki kapasitas untuk merespon panggilannya sendiri. ${ }^{11}$ "Pendidik maupun peserta didik adalah history maker (pencipta-pencipta sejarah)." 12 Hal itu berarti pendidik harus menyadari bahwa dirinya bukanlah satu-satunya yang penting dalam proses belajar. Pendidik perlu membangun suatu hubungan kemitraan dengan peserta didik. Pendapat ini juga didukung oleh Groome yang menyatakan bahwa, peserta didik merupakan rekan seperjalanan yang mengembara dalam waktu dan tempat tertentu bersama dengan pendidik. ${ }^{13}$ Oleh sebab itu, peserta didik haruslah diperlakukan sebagai subjek yang memiliki kemampuan serta hak untuk membangun pemikirannya, kemudian mendefinisikan diri mereka sendiri, menyampaikan ide serta gagasan yang dimilikinya, dan

${ }^{11}$ Daniel Nuhamara, Pembimbing PAK, 154.

${ }^{12}$ Daniel Nuhamara, Pembimbing PAK, 154-155.

${ }^{13}$ Thomas H. Grome, Christian Religious Education: Sharing Our Story and Vision (San Fransisco: Harper, 1980), 85. 
mengambil keputusan. Hal ini penting untuk dipahami oleh pendidik sebelum mengajarkan pendidikan perdamaian kepada peserta didiknya. Keselarasan hubungan antara peserta didik dan pendidik serta cara pandang pendidik terhadap peserta didik ikut menentukan keberhasilan proses pendidikan perdamaian.

Tulisan ini akan fokus kepada anak sebagai salah satu subjek pembelajar dalam pendidikan perdamaian. Pada masa kanak- kanak, anak mengalami yang disebut sebagai proses sosialisasi primer, yakni proses yang paling awal, di mana seorang anak membentuk konsep dirinya sehingga pada akhirnya mampu berelasi dan menjadi bagian dari masyarakat. ${ }^{14}$ Sosialisasi primer merupakan fase yang paling penting, karena seperti apa dan bagaimana ia di masa depan (saat dewasa), ditentukan oleh fase primer ini. Jika sejak dini anak banyak belajar tentang perdamaian, maka ia akan mengonsepkan dirinya sebagai pembawa damai dan berperilaku serta membangun relasi dengan sekitarnya dengan cara-cara yang damai, sehingga tercipta sebuah masyarakat yang damai pula. Dengan demikian, pendidikan perdamaian sangat efektif diajarkan pada anak-anak.

Hal yang perlu diperhatikan adalah bahwa setiap anak perlu dididik dengan cara yang relevan dan dapat dimengerti oleh mereka, karena secara kualitatif mereka memiliki cara pikir yang berbeda dengan orang dewasa. Pendidikan perdamaian yang diajarkan dengan tepat kepada anak sesungguhnya akan menjadi sebuah fondasi, yang di dalamnya berisi nilainilai dan warisan-warisan yang mengandung kekuatan besar dalam pembentukan karakternya sebagai pembawa damai. Pada akhirnya, kualitas keluarga, komunitas iman, dan bangsa akan ditentukan oleh kualitas anak-anak tersebut.

Yesus sendiri memberi perhatian khusus terhadap kehidupan anakanak. Hal ini dikemukakan oleh salah seorang teolog pembebasan, Joice Ann Mercer, yang mencoba menyoroti anak berdasarkan Injil Markus sebagai sebuah individu yang berharga sehingga ia tidak boleh ditindas dan memiliki kesempatan untuk mendapatkan pendidikan yang benar dalam pengenalan akan Allahnya. ${ }^{15}$ Mercer menentukan perspektifnya dalam membaca teks Markus tentang gerakan Yesus dari perspektif sosiopolitis feminis kristis, secara khusus dalam solidaritas dengan anak-anak. Dalam hal ini, Mercer melihat Markus sebagai narasi tandingan terhadap dominasi rezim imperial pada waktu itu.

Berdasarkan konteks sosio-politis, Injil Markus berlatarkan desa agraris di bawah pemerintahan Roma yang damai. ${ }^{16}$ Pemerintah Roma

${ }^{14}$ Daniel Nuhamara, Pembimbing PAK, 54.

${ }^{15}$ Joyce A. Mercer, Welcoming Children: A Practical Theology of Childhood (Missouri:

Chalice Press, 2005), 24-29.

${ }^{16}$ Joyce A. Mercer, Welcoming Children: A Practical Theology of Childhood, 46-47. 
dengan sengaja memilih elit-elit lokal untuk dijadikan penguasa setempat dengan harapan tidak ada pemberontakan. Mereka juga menggunakan kekuatan militer untuk meminimalisir perlawanan. Oleh sebab itu, pemerintahan yang damai ini sesungguhnya merupakan penjajahan politis dan ekonomis kepada orang-orang tertindas dengan memungut pajak demi membiayai pembangunan dan tentaranya. Kondisi yang demikian menyebabkan orang Galilea pedesaan mengalami tiga macam penindasan. Mereka harus membayar pajak kepada kaisar, kepada pimpinan lokal/gubernur, dan kepada pengurus bait Allah. ${ }^{17}$ Keadaan ini memaksa penduduk untuk menjual harta benda mereka. Perempuan dan anak-anak juga dijual untuk memenuhi kewajiban mereka.

Satu poin penting yang diangkat oleh Mercer adalah bahwa Injil Markus muncul sebagai narasi tandingan, di mana proklamasi Yesus tentang Kerajaan Allah adalah oposisi terhadap pemerintahan kekaisaran..$^{18}$ Kerajaan Allah yang diproklamasikan Yesus adalah situasi dan kondisi damai yang tidak semu dan berlaku bagi semua, termasuk anak-anak. Yesus ingin menyatakan bahwa Allah mengasihi dan menganggap anak-anak penting dan berharga. ${ }^{19}$ Anak-anak yang sering dikucilkan, yang seolah tidak memiliki hak, juga memiliki andil dalam mewujudkan Kerajaan Allah. Hal ini berarti anak-anak perlu dipersiapkan untuk mengemban misi mewujudkan Kerajaan Allah, di mana di dalamnya ada kasih, keadilan, dan perdamaian bagi seluruh ciptaan. Dengan demikian, anak memiliki hak untuk dibekali dengan berbagai pengetahuan, keterampilan, dan harus dilatih untuk memenuhi panggilannya sebagai agen Kerajaan Allah yang mampu menghadirkan perdamaian.

\section{Gereja sebagai Konteks Pendidikan Perdamaian bagi Anak}

Penulis menyadari bahwa pendidikan perdamaian bagi anak dapat dilakukan dalam berbagai konteks. Pendidikan Perdamaian dapat dilakukan di dalam keluarga, sekolah, lingkungan, melalui media massa, serta dapat dilakukan dalam komunitas iman. Tulisan ini akan fokus pada konteks komunitas iman, yang dalam hal ini adalah Gereja.

Sumiyatiningsih menyatakan sebagai berikut:

Dari sejak semula komunitas Kristen bertumbuh dengan tujuan bahwa iman mereka akan ditopang dan dihayati oleh setiap orang dalam komunitas tersebut, di mana masing-masing orang akan saling menguatkan dan menjaga keutuhan iman mereka kepada Tuhan. Oleh sebab itu, perlu adanya

${ }^{17}$ Joyce A. Mercer, Welcoming Children: A Practical Theology of Childhood, 47-49.

${ }^{18}$ Joyce A. Mercer, Welcoming Children: A Practical Theology of Childhood, 49.

${ }^{19}$ Joyce A. Mercer, Welcoming Children: A Practical Theology of Childhood, 50. 
suatu pengajaran iman Kristen yang baik sehingga iman mereka akan bertumbuh dengan benar. ${ }^{20}$

Pernyataan tersebut secara langsung berimplikasi pada tugas gereja yang tidak boleh dibatasi hanya pada usaha menjaga spiritualitas dan keimanan warganya, tetapi juga pada segi edukatif yakni mendidik warga gerejanya agar memiliki pemahaman yang mendalam mengenai kekristenan itu sendiri, sehingga dapat bertumbuh menjadi orang Kristen yang dewasa.

Pada dasarnya, perdamaian merupakan salah satu inti ajaran yang paling esensial dalam iman Kristen. Yesus, melalui khotbah di bukit menyatakan bahwa orang yang membawa damai akan disebut sebagai anak-anak Allah. ${ }^{21}$ Yesus Sang Anak, tunduk pada kehendak Bapa-Nya turut serta memproklamirkan misi perdamaian ini. Meski demikian, misi perdamaian itu tidak berhenti dalam diri Yesus saja, tetapi dimandatkan juga kepada gereja. Gereja terpanggil untuk mengemban, menjiwai, mewariskan misi tersebut, melalui usaha pendidikan dan usaha-usaha lain bagi seluruh warganya termasuk anak-anak. Dengan demikian, pertumbuhan iman anak-anak ke arah cinta akan perdamaian yang merupakan esensi dari iman Kristen juga merupakan tanggung jawab Gereja.

Pendidikan Perdamaian dalam konteks gereja terjadi dalam tiga setting yaitu, jemaat lokal, gereja-gereja pada aras klasis atau sinode, maupun pada aras interdenominasi. Dalam pembahasan kali ini, penulis akan mengkaji pendidikan perdamaian dalam konteks gereja sebagai jemaat lokal. "Jemaat lokal adalah persekutuan orang-orang percaya yang terikat dalam suatu organisasi pada tingkat lokal." ${ }^{22} \mathrm{Hal}$ ini menunjukkan adanya suatu proses yang terstruktur dalam organisasi gereja, di mana para anggotanya berinteraksi secara intim dan berkualitas dalam rangka mencapai suatu tujuan. Tujuan dalam konteks ini adalah terciptanya perdamaian.

Westerhoff III memberikan beberapa ciri dari jemaat lokal sebagai suatu persekutuan Kristen yang relevan, yaitu memiliki kesatuan esensial, 2006), 29.

${ }^{20}$ Dien Sumiyatiningsih, Mengajar dengan Kreatif dan Menarik (Yogyakarta: ANDI,

${ }^{21}$ Lihat Matius 5:9. Yesus menyebut orang-orang yang membawa damai sebagai anak-anak Allah. Kata "anak" menggambarkan suatu ikatan yang sangat dekat. Seorang anak tentu mewarisi sifat Bapanya, serta mendapat didikan dari Bapanya. Dalam hal ini, pembawa damai adalah salah satu dari sifat Allah, dan Allah menghendaki agar anakanak-Nya mampu menjadi pembawa damai. Tetapi, anak bukanlah Bapa, sehingga anak harus belajar untuk membiarkan otoritas Bapa berlaku dalam kehidupan anak, agar anak menjadi serupa dengan Bapa, dan dengan demikian mereka layak diakui sebagai anak-anak Bapa.

${ }^{22}$ Daniel Nuhamara, Pembimbing PAK, 70. 
interaksinya dilakukan dalam jumlah lebih kecil, tiap anggota dalam persekutuan dapat dikategorikan berdasarkan generasinya, dan terdiri dari orang-orang yang berbeda-beda namun bersatu dan saling menopang. ${ }^{23}$ Keempat ciri tersebut menggambarkan bahwa pendidikan perdamaian harus dilakukan dalam suatu situasi dan kondisi yang memadai, di mana selalu ada kemauan untuk saling mendukung pertumbuhan rasa cinta damai di dalam anggota jemaat. Di dalam konteks jemaat lokal, pendidikan perdamaian dapat mengambil bentuk melalui pelayanan kategorial. "Pelayanan kategorial muncul karena adanya kesadaran akan kekhasan tiap kelompok usia dari segi kebutuhan, minat, persoalan, maupun tingkat pertumbuhannya." 24 Pendidikan perdamaian bagi anak di gereja dapat dilakukan melalui pelayanan kategorial anak seperti sekolah minggu.

Sejak semula sekolah minggu memiliki peranan yang cukup besar dalam hidup anak-anak. Hal ini dimulai sejak revolusi industri beberapa abad yang lalu. Awalnya ide sekolah minggu dicetuskan oleh Robert Raikes, yang peduli terhadap anak-anak jalanan yang mulai membuat kericuhan. Robert Raikes membuat sekolah minggu sebagai tempat bagi anak-anak untuk belajar membaca dan berhitung, dengan harapan mereka akan menjadi terdidik dan tidak berbuat ricuh lagi. ${ }^{25}$ Sekolah Minggu dianggap sebagai solusi untuk menciptakan kedamaian bagi masyarakat yang mulai merasa terganggu dengan keberadaan anak-anak jalanan tersebut. Pendidikan yang diberikan di Sekolah Minggu diharapkan mampu membawa perubahan bukan hanya pada hal kognitif saja melainkan juga pada sikap hati dan perilaku.

Saat ini, Sekolah Minggu telah mengalami banyak perkembangan. Sekolah Minggu tidak lagi sekedar menjadi sarana untuk membaca, menulis, berhitung, namun sebagai suatu sarana untuk bersekutu, belajar bersama dan saling menguatkan di dalam terang Tuhan. ${ }^{26} \mathrm{Hal}$ yang tidak berubah adalah bahwa Sekolah Minggu tetap menjadi sarana bagi anak untuk belajar menjadi baik. Dengan demikian, Sekolah Minggu yang telah diambil alih menjadi bagian dari pelayanan kategorial gereja tentu memiliki peran yang signifikan dalam melaksanakan pendidikan perdamaian bagi anak-anak pada masa kini.

Meskipun pelayanan kategorial seperti Sekolah Minggu dapat menjadi sarana yang efektif untuk pendidikan perdamaian bagi anak,

\footnotetext{
1976), 45.

${ }^{24}$ Daniel Nuhamara, Pembimbing PAK, 74.

${ }^{25}$ Robert R.Boehlke, Sejarah Perkembangan Pikiran dan Praktek Pendidikan Agama Kristen (Jakarta: BPK Gunung Mulia, 2009), 378.

${ }^{26}$ Robert R. Boehlke, Sejarah Perkembangan Pikiran dan Praktek Pendidikan Agama Kristen, 398.
}

${ }^{23}$ John Westherhoff, Will Our Children Have Faith? (New York: Seabury Press, 
namun pelayanan anak ini tidak boleh berdiri sendiri. Ia tetap berakar pada gereja induknya dan perlu menjalin kerjasama dengan pelayanan kategorial yang lain. Hal ini bukan hanya berfungsi untuk membangun suatu pelayanan yang berkelanjutan tetapi lebih daripada itu, anak perlu merasa menjadi bagian dari gereja, bukan hanya bagian dari Sekolah Minggu.

\section{Model Pendidikan Perdamaian bagi Anak dalam Konteks Gereja}

Menurut KBBI, "Model adalah pola (contoh, acuan, ragam, dsb) dari sesuatu yang akan dibuat dan dihasilkan." 27 Dalam dunia pendidikan, model diartikan sebagai gambaran interaksi antara pendidik dan peserta didik dalam proses belajar mengajar, yang akan menentukan kualitas pengalaman belajar peserta didik. ${ }^{28} \mathrm{Jadi}$, model pendidikan perdamaian adalah gambaran interaksi antara peserta didik dan pendidik dalam berbagai kegiatan pembelajaran yang bertujuan untuk mendidik dan mempersiapkan peserta didik menjadi agen-agen perdamaian.

Berdasarkan kajian penulis terhadap definisi-definisi dari pendidikan perdamaian, penulis melihat bahwa pendidikan perdamaian perlu dilakukan secara bertahap, di mana setiap tahapnya saling terhubung, berurutan, berkelanjutan, dan dapat dikembangkan. Tahapan-tahapan ini akan membantu pendidik untuk membimbing peserta didik secara holistik menjadi agen-agen perdamaian. Menurut hemat penulis, ada tiga tahap dalam melaksanakan pendidikan perdamaian yaitu, tahap penyadaran, tahap penghayatan, dan tahap penerapan. Setiap tahap akan menyajikan beragam model pendidikan perdamaian bagi anak dalam konteks gereja.

Tahap dan model pendidikan perdamaian bagi Anak dalam konteks gereja dapat dilihat dalam tabel berikut ini: ${ }^{29}$

\footnotetext{
${ }^{27}$ Kamus Besar Bahasa Indonesia Online, diakses 2 November 2017, http://kbbi.web.id/model., s.v. "Model"

28 Dien Sumiyatiningsih, Mengajar dengan Kreatif dan Menarik, 70.

29 Tabel tahap dan model pendidikan perdamaian ini merupakan hasil kajian penulis terhadap teori-teori yang telah penulis paparkan sebelumnya mengenai pendidikan perdamaian. Setiap tahap memiliki model yang berbeda-beda. Model yang penulis kemukakan dalam setiap tahap menyesuaikan apa yang ingin dicapai pada masing-masing tahap tersebut, yakni menyadarkan, menumbuhkan penghayatan, dan mendorong peserta didik menerapkan sikap dan perilaku sebagai pembawa damai. Beberapa model merupakan model-model pembelajaran yang umumnya sudah digunakan dalam dunia pendidikan, namun untuk model integrasi (dengan kalender gerejawi) dan model kontemplatif merupakan gagasan penulis yang muncul dari konteks pelaksanaan pendidikan perdamaian itu sendiri yakni gereja.
} 
Tabel 1. Tahap dan Model Pendidikan Perdamaian

\begin{tabular}{|l|l|}
\hline Tahap & Model \\
\hline Tahap penyadaran & $\begin{array}{l}\text { Model kontemplatif dan model Problem- } \\
\text { posing. }\end{array}$ \\
\hline Tahap penghayatan & $\begin{array}{l}\text { Model Integrasi (dengan kalender } \\
\text { gerejawi) dan model bermain peran. }\end{array}$ \\
\hline Tahap penerapan & Model aksi-refleksi. \\
\hline
\end{tabular}

\section{Tahap Penyadaran}

Tahap ini merupakan tahap awal dalam proses pendidikan perdamaian. Pada tahap ini seseorang akan lebih banyak melibatkan kemampuan kognitifnya dalam proses pendidikan perdamaian. Sebelum seseorang menjadi agen perdamaian, mereka perlu mengawali prosesnya dengan sebuah kesadaran kritis bahwa perdamaian adalah hal yang positif bagi keberlangsungan hidup manusia. Kesadaran kritis akan menempatkan hal-hal dan fakta-fakta secara empiris sebagaimana adanya, baik dalam hubungan kausal maupun dalam hubungan tidak langsung. ${ }^{30}$ Kesadaran kritis dibutuhkan untuk mengemukakan fakta bahwa lingkungan di mana manusia tinggal saat ini berada pada kondisi darurat perdamaian. Oleh sebab itu, pendidikan perdamaian dibutuhkan untuk mengatasi masalah tersebut.

Pada dasarnya, tahap penyadaran merupakan tahap untuk membuat peserta didik memahami bukan hanya signifikansi perdamaian tetapi juga kekuatan dari perdamaian. Harris dan Morrison menyatakan bahwa, kekerasan berkembang pesat dalam dunia modern karena banyak orang melihat kekerasan sebagai hal yang kuat, sementara itu perdamaian terkesan lemah. ${ }^{31}$ Mereka tidak mau menggali potensi dari perdamaian dan menemukan kekuatannya dalam kehidupan. Banyak orang menganggap bahwa perdamaian adalah sesuatu yang idealis dan utopis. Melalui tahap ini, peserta didik akan menjadi optimis dengan perdamaian dan percaya bahwa dunia akan jauh lebih baik dengan perdamaian dibandingkan dengan kekerasan.

Tidak hanya itu, tahap ini juga merupakan tahap di mana peserta didik akan menyadari panggilannya sebagai agen perdamaian. Sebagaimana manusia mengaku bahwa dirinya adalah anak-anak Allah, ciptaan Allah, maka mereka akan menerima diri dengan ungkapan syukur dan mengonsepkan dirinya sebagai agen-agen Tuhan bagi perdamaian dunia. Kesadaran itu akan membawa peserta didik pada kepercayaan diri 39.

${ }^{30}$ Paulo Freire, Education for Critical Conciousness (New York: Continuum, 2005),

${ }^{31}$ Ian Harris dan Mary Morrison, Peace Education: Third Edition (North Carolina: McFarland \& Company, Inc., Publishers, 2013), 49. 
bahwa mereka dibutuhkan untuk menjaga perdamaian di tempat mereka berada.

Kesadaran, optimisme, dan panggilan terhadap perdamaian yang dibangun dalam diri peserta didik tentu tidak dapat dilakukan dalam cara-cara indoktrinasi. Kamus Besar Bahasa Indonesia mendefinisikan indoktrinasi sebagai pemberian ajaran secara mendalam (tanpa kritik) dengan melihat kebenaran dari satu sisi saja. ${ }^{32}$ Indoktrinasi sesungguhnya tidak cocok dan tidak selaras dengan definisi dan tujuan dari pendidikan perdamaian yang salah satunya adalah membangun kesadaran. Kesadaran harus muncul secara alamiah dalam diri peserta didik, sehingga mereka dapat membuat suatu komitmen, bukan karena dipaksa mendengar atau menerima apa yang diajarkan. Dalam hal ini, penulis mengusulkan 2 model pendidikan perdamaian untuk mendukung tahap penyadaran ini yaitu, model kontemplatif dan model problem-posing.

\section{Model Kontemplatif}

Model kontemplatif umumnya jarang dilakukan dalam proses belajar mengajar. Namun, penulis menjadikannya sebagai salah satu model pelaksanaan pendidikan perdamaian bagi anak karena cocok dengan konteks gereja. "Kontemplatif adalah renungan dan sebagainya dengan kebulatan pikiran atau perhatian penuh." 33 Melalui model ini, anak akan diajak untuk merenungkan dan memikirkan siapa diri mereka, hal-hal apa yang membuat mereka senang, hal-hal apa yang membuat mereka bersedih. Mereka akan membayangkan seperti apa mereka saat dewasa dan dalam kondisi bagaimana mereka hidup. Mereka akan merenungkan lebih dalam dan mencapai suatu kesimpulan semuanya dapat terjadi jika mereka hidup dalam suasana damai.

Model ini sesungguhnya sangat cocok diterapkan bagi anak-anak, karena anak-anak penuh dengan imajinasi. Mereka umumnya selalu membayangkan diri sebagai superhero yang memiliki banyak kekuatan dan jurus-jurus untuk memperjuangkan kebaikan dan kedamaian di dunia. Dalam hal ini, pendidik perlu kreatif dan tanggap dalam mengorelasikan antara imajinasi mereka dengan panggilannya sebagai agen-agen perdamaian.

Model ini menuntut pendidik untuk mempersiapkan sebuah narasi yang akan membawa anak-anak tersebut, masuk dalam perenungan yang lebih dalam tentang panggilan hidup yang sesungguhnya. Keberhasilan model ini memang terletak pada kemampuan pendidik untuk

32 Kamus Besar Bahasa Indonesia Online, diakses 5 November 2017, http://kbbi.web.id/indoktrinasi, s.v. "Indoktrinasi"

${ }^{33}$ Kamus Besar Bahasa Indonesia Online, diakses 5 November 2017, http://kbbi.web.id/kontemplatif, s.v. "Kontemplatif" 
menggunakan pernyataan-pernyataan yang jelas dan sederhana, yang dapat dengan mudah dipahami oleh peserta didik, sehingga ia berhasil menemukan diri melalui perenungannya.

\section{Model Problem-Posing}

Secara harfiah kata problem-posing dapat diartikan menghadapi masalah. Problem posing pertama kali diperkenalkan oleh Paulo Freire melalui tulisannya Pedagogy of the Oppressed. Freire mencoba melihat kemungkinan adanya suatu transformasi dalam masyarakat kelas bawah yang tertindas melalui hadirnya pendidikan yang membebaskan. ${ }^{34}$ Dalam bukunya Freire mengkritisi dunia pendidikan yang menggunakan model banking. Model pendidikan banking selalu menyebabkan peserta didik menjadi pasif, membangun budaya "diam" dan memosisikan peserta didik sebagai obyek bukan subjek, yang tidak mungkin memiliki pengaruh bagi sejarah dan lembaga. ${ }^{35}$ Sebagai gantinya, Freire menawarkan model problem-posing yang dapat mendorong siswa untuk menjadi aktif berpikir dan bertindak atas dunia mereka. ${ }^{36}$ Model problem-posing akan membawa peserta didik dalam kesadaran yang akan menuntunnya bertindak memutuskan cara pernyelesaian masalah dengan pertimbangan yang matang.

Problem-posing mula-mula membuat peserta didik sadar dengan masalah-masalah yang ada di sekelilingnya. Dalam konteks pendidikan perdamaian, anak-anak dapat mengidentifikasikan hal-hal yang menyebabkan lingkungannya menjadi tidak damai berdasarkan apa yang mereka alami maupun ketahui, kemudian mereka diminta untuk menjelaskan persepsinya mengenai hal itu, dan memikirkan solusinya. Pendidik berpikir bersama peserta didik. Ia melihat semua kemungkinan yang ada, ikut menganalisis dan memberitahukan pertimbangan atau perspektif lain sehingga pengetahuan dibangun secara bersama-sama melalui dialog dan interaksi. Keberhasilan dari model ini adalah ketika peserta didik menjadi peka dengan apa yang dialami, kemudian bersedia menghadapinya atau mencari solusi dengan cara-cara damai.

\section{Tahap Penghayatan}

Tahap ini merupakan tahap yang kedua dalam melaksanakan pendidikan perdamaian. Tahap ini banyak melibatkan kemampuan afektif dari peserta didik. Pendidik mencoba membangun situasi di mana peserta didik mampu menghayati makna dari perdamaian dan pentingnya menjadi pembawa damai.

${ }^{34}$ Paulo Freire, Pedagogy of The Oppressed (New York: Continuum, 2005), 79.

${ }^{35}$ Paulo Freire, Pedagogy of The Oppressed, 75.

${ }^{36}$ Paulo Freire, Pedagogy of The Oppressed, 79-83. 
Pada tahap sebelumnya, rasio menjadi sangat dominan, namun meski demikian kesadaran tidak boleh berhenti pada rasionalitas semata. Menurut Freire, kesadaran yang intensional adalah kesadaran yang totalitas, yakni yang tidak hanya melibatkan rasio, tetapi juga perasaan, emosi, dan keinginan. ${ }^{37}$ Pada dasarnya penghayatan menjadi langkah selanjutnya setelah seseorang mulai sadar. Dalam tahap ini peserta didik akan diarahkan untuk mencintai, merindukan, dan mendambakan perdamaian secara natural. Mereka perlu memperoleh pengalaman berupa perasaan nyaman ketika menjadi pembawa damai dan hidup bersama dalam kedamaian. Tujuan tahap ini adalah peserta didik dapat menghayati makna dalam setiap proses sehingga ia merasa menjadi bagian dari perwujudan perdamaian. Adapun model yang penulis usulkan untuk mendukung tahap ini adalah model integrasi dan model bermain peran.

\section{Model Integrasi (dengan kalender gerejawi)}

Model integrasi merupakan model yang mencoba mengkombinasikan dan menyatukan nilai-nilai tertentu yang hendak dipelajari dengan peristiwa-peristiwa penuh makna yang ada di sekitarnya. Pendidikan perdamaian yang dilakukan dalam konteks gereja mengandung nilai-nilai positif seperti cinta, keadilan, pengampunan, rasa syukur, kelemahlembutan, dan sebagainya, yang akan dimaknai secara mendalam melalui simbol-simbol spiritual maupun peristiwa penting gereja. Hal ini berguna bagi peserta didik dalam proses pemaknaan dan penghayatannya sebagai bagian dari gereja yang memegang mandat sebagai agen perdamaian. Model ini juga membantu gereja agar peristiwaperistiwa yang sarat makna tersebut tidak hanya menjadi rutinitas melainkan berdampak dalam diri warganya.

Kekuatan utama dalam tradisi pendidikan Yahudi, khususnya pada masa Perjanjian Lama sesungguhnya terletak pada sosialisasi, di mana anak-anak ikut menyaksikan, merasakan, bahkan memiliki peran dalam komunitas. ${ }^{38}$ Ritus-ritus atau peristiwa-peristiwa spiritual sarat makna dihayati sebagai bagian dalam kehidupan sehari-hari, sehingga meskipun belum ada sekolah atau synagoge pada waktu itu, belajar telah menjadi bagian dalam kehidupan mereka. Hal ini juga yang menginspirasi penulis untuk mengusulkan model integrasi (dengan kalender gerejawi).

Menurut penulis, kekuatan model ini terletak pada keunikan ritual ataupun simbol-simbol tertentu dan kualitas pokok kajian yang hendak disampaikan sesuai dengan peristiwa-peristiwa penting tersebut melalui proses sosialisasi. Misalnya, pada masa pra-Paskah sampai Paskah.

\footnotetext{
${ }^{37}$ Paulo Freire, Pedagogy of The Hearth (New York: Continuum, 2000), 94.

${ }^{38}$ Lawrence O. Richards, Nurturing Faith within The Family of God (USA: The Zondervan Corporation, 1983), 19-20.
} 
Peserta didik, dalam hal ini anak-anak, tentu mengikuti dan menyaksikan ritual-ritual selama masa pra-Paskah, mulai dari Minggu awal pra-Paskah hingga Minggu Palmarum, Kamis Putih dan Jumat Agung dengan Sakramen Perjamuan Kudus, sampai kepada Minggu Paskah. Anak-anak harus dihantar untuk merasakan makna di balik ritual dan simbol-simbol tersebut. Mereka juga diajak bukan hanya untuk mendengarkan cerita bagaimana proses Yesus disalib, tetapi merasakan bagaimana perasaan Yesus yang harus menderita untuk dunia yang membencinya dan bagaimana Yesus menjalankan perannya sebagai pembawa damai sehingga diperingati dalam nuansa-nuansa spiritual yang mereka alami dalam gereja. Mereka diajak untuk merasakan kekuatan dari nilai perdamaian di balik cerita dan simbol yang mereka dengar dan lihat, bukan hanya sekadar mengetahuinya. Semakin mampu mereka merasakan, semakin dalam penghayatan mereka terhadap pentingnya perdamaian dan semakin sering mereka mendambakan terwujudnya perdamaian. Dengan demikian, sosialisasi simbol dan peristiwa penting dalam gereja adalah sarananya, nilai-nilai perdamaian adalah substansinya, sedangkan penghayatan dan kerinduan terhadap perdamaian adalah hasilnya.

\section{Model Bermain Peran}

Meskipun banyak melibatkan aktivitas motorik, model ini sesungguhnya dikategorikan dalam tahap penghayatan, karena melalui model ini peserta didik akan belajar menghayati peran dan nilai-nilai yang terkandung di dalamnya. Model ini juga dapat digunakan apabila pendidik menghendaki aktivitas yang membutuhkan interaksi dengan orang lain maupun aktivitas pribadi.

Menurut Joyce, "Role Playing mengeksplorasi bagaimana nilai-nilai mendorong perilaku dan menaikkan kesadaran siswa tentang peran nilainilai dalam kehidupan mereka dan kehidupan orang lain." ${ }^{39}$ Peran adalah rangkaian perasaan, ucapan, dan tindakan. ${ }^{40}$ Melalui peran yang dijalankan, kekuatan dari nilai-nilai yang diperankan dihidupkan dalam dirinya sehingga memunculkan penghayatan dalam ucapan dan perilakunya. Anak-anak dapat belajar untuk menghayati perannya sendiri dan peran orang lain sekaligus mengerti sikap, perasaan, dan nilai-nilai yang mendasarinya melalui model ini. Menurut penulis, pesan atau informasi dapat dihayati dengan baik apabila si penerima pesan langsung mempraktikkannya sebagaimana ia adalah si pemberi pesan. Sebagai contoh, ketika membahas tema "Ada Perdamaian dalam Perbedaan." Tema ini sangat abstrak bagi anak-anak, namun apabila pendidik

\footnotetext{
${ }^{39}$ Bruce Joyce, dkk, Models of Teaching (Yogyakarta: Pustaka Pelajar, 2016), 412.

${ }^{40}$ Dien Sumiyatiningsih, Mengajar dengan Kreatif dan Menarik, 83.
} 
mengajarkannya dengan model bermain peran, maka hal yang abstrak dapat dikongkretkan dan disederhanakan, sehingga dapat dihayati dan dipahami dengan baik. Pendidik hanya perlu membiarkan anak-anak berekspresi dengan bebas sesuai dengan apa yang ia pahami dan hayati tentang peran, cerita, dan nilai-nilai di dalamnya. Untuk mengetahui keberhasilan dari model ini, pendidik perlu melakukan konfirmasi, sehingga dapat diketahui sejauh mana mereka menghayati peran yang dimainkan.

\section{Tahap Penerapan}

Tahap penerapan adalah tahap terakhir dalam pendidikan perdamaian. Tahap ini adalah tahap yang memberi ruang bagi peserta didik untuk mempraktikkan apa yang selama ini telah diketahui, dipahami, dan dihayati berkaitan dengan perdamian. Menurut Groome, setiap komunitas kristiani memiliki tanggung jawab untuk menciptakan sebuah "hubungan yang benar" dengan "melakukan kebenaran berdasarkan kasih" dan menolong seseorang untuk menciptakan suatu struktur sosial dan memampukan yang lain untuk berbuat hal yang serupa. ${ }^{41} \mathrm{Hal}$ ini menyebabkan pendidikan perdamaian tidak akan pernah menjadi lengkap tanpa praktik.

Tahap ini menitikberatkan pada tindakan sebagai respons atas proses pembelajaran di dalam kelas. Keberhasilan dari pendidikan perdamaian tentu dapat dilihat melalui tahap ini. Meski demikian kekuatan-kekuatan pada tahap sebelumnya tidak dapat dilepaskan dan memengaruhi keberhasilan tahap ini. Adapun model yang penulis usulkan untuk mendukung tahap ini adalah model aksi-refleksi.

\section{Model Aksi-Refleksi}

"Adapun fokus dari pada model ini adalah melakukan kebenaran melalui proses berpikir dengan memasukkan berbagai informasi dan mengevaluasi tindakan atau aksi." 42 "Hal ini berarti model aksi refleksi membutuhkan analisis situasi, memanfaatkan baik tradisi maupun disiplin ilmu untuk memecahkan masalah, menguji, dan meneliti asumsi yang dipakai. Semua aspek tersebut membawa tindakan atau aksi untuk berelasi dengan pemikiran." ${ }^{43}$ Dengan kata lain, tindakan seseorang menunjukkan atau mencerminkan prinsip, nilai, dan keyakinan seseorang, yang benar-benar dipercayai dan penting baginya.

Pada dasarnya, perdamaian bukan hanya perlu dipikirkan ataupun direfleksikan, lebih dari itu perdamaian perlu diwujudkan dalam

\footnotetext{
${ }^{41}$ Thomas H. Grome, Christian Religious Education: Sharing Our Story and Vision, 400.

42 Dien Sumiyatiningsih, Mengajar dengan Kreatif dan Menarik, 101.

${ }^{43}$ Dien Sumiyatiningsih, Mengajar dengan Kreatif dan Menarik, 102-103.
} 
tindakan sebagai respons terhadap iman. Misalnya ketika anak-anak diperhadapkan pada masalah seperti permusuhan dengan teman, model ini akan membantu anak-anak untuk merefleksikan sikap bermusuhan sebagai sikap yang tidak mencerminkan iman Kristen dan tidak dikehendaki oleh Tuhan. Melalui model ini anak-anak diharapkan mencari referensi dari tradisi-tradisi kristiani dalam Alkitab. Berdasarkan referensi itu anak-anak kemudian merumuskan, menyimpulkan, dan menanggapi secara sederhana masalah konkret yang dihadapi berdasarkan imannya. Setelah memahami hal tersebut, anak-anak diharapkan dapat merencanakan dan mempraktikkan aksi baru sebagai tindak lanjut dari refleksi yang telah dilakukannya. Dengan demikian, melalui model ini, anak-anak dapat belajar untuk memiliki sikap tanggap terhadap masalah-masalah yang ada di sekitarnya.

Hal yang paling penting adalah pendidik sungguh-sungguh memberi tempat bagi mereka untuk mempraktikkannya secara nyata. Seringkali model ini berhenti ketika anak telah berhasil memutuskan dan merencanakan aksi baru. Keberhasilan model ini terletak pada aksi nyata yang dilakukannya, bukan sebatas rencana untuk beraksi. Meskipun demikian, model ini sulit diterapkan kepada anak-anak yang berusia di bawah tujuh tahun, karena mereka belum mampu menganalisis lebih dalam dan belum mampu mengambil keputusan. Oleh sebab itu, pendidik perlu berhati-hati dan menyesuaikan perkembangan anak saat menerapkannya.

\section{Kesimpulan}

Pendidikan perdamaian adalah suatu usaha yang kompleks karena mengandung berbagai tujuan yakni untuk menumbuhkan komitmen, menanamkan rasa cinta akan kedamaian, sampai memampukan peserta didik untuk melakukan analisis kritis dan menyelesaikan konflik dengan cara damai sehingga mereka layak disebut sebagai agen perdamaian. Pendidikan perdamaian disebut menyeluruh karena tidak hanya meliputi masalah relasi antar manusia, tetapi juga masalah relasi manusia dengan lingkungan, serta mencakup tidak hanya hal-hal kognitif, tetapi juga afektif, dan psikomotorik.

Pendidikan perdamaian sesungguhnya lebih efektif jika diterapkan pada anak-anak. Fase sosialisasi primer yang dimiliki anak, serta waktu pembelajaran sedini mungkin membuat nilai-nilai perdamaian lebih mudah mengakar dan menjadi fondasi yang kuat bagi pertumbuhannya sebagai calon pembawa damai. Yesus juga menghargai anak-anak sebagai bagian dari komunitas pengemban misi Kerajaan Allah, di mana ada perdamaian di dalamnya. Oleh karena itu, anak-anak juga perlu diperlengkapi hingga akhirnya siap mengemban misi tersebut. 
Gereja sebagai komunitas iman memiliki berbagai peran, tugas, dan tanggung jawab yang salah satunya adalah mendidik seluruh warganya, termasuk anak-anak untuk mengemban misi mewujudkan perdamaian. Meskipun anak-anak memiliki wadah persekutuan dan pembelajaran pada salah satu pelayanan kategorial gereja, seperti Sekolah Minggu, namun anak perlu merasa bahwa dia juga adalah anggota gereja, bukan hanya anggota Sekolah Minggu.

Pendidikan perdamaian bagi anak dalam konteks gereja perlu dilakukan dalam tiga tahap, yakni tahap penyadaran, penghayatan, dan penerapan. Tahap penghayatan banyak melibatkan ranah kognitif melalui model kontemplatif dan model problem-posing. Kedua model tersebut berguna untuk membangkitkan kesadaran dalam diri peserta didik tentang pentingnya perdamaian dan tentang perannya sebagai pembawa damai. Tahap yang kedua adalah penghayatan, di mana nilai-nilai perdamaian akan dibangkitkan melalui sebuah penjiwaan yang mendalam melalui model integrasi (dengan kalender gerejawi) dan model bermain peran. Tahap yang ketiga adalah tahap penerapan. Tahap ini banyak melibatkan ranah psikomotorik yang telah banyak dipengaruhi oleh tahap-tahap sebelumnya. Pada tahap ini peserta didik diajak mengambil keputusan dan bersikap kritis sehingga benar-benar menerapkan perdamaian dan menjadi agen perdamaian.

Pada dasarnya penulis menyadari bahwa tulisan ini memiliki keterbatasan, hal ini berkaitan dengan aplikasi model-model pendidikan perdamaian bagi anak dalam konteks gereja-gereja di Indonesia. Model yang penulis bangun hanya berdasarkan kajian teoritis terhadap sumber pustaka yang penulis pilih. Dengan demikian, efektifitas dari model ini belum dapat diketahui secara pasti, sehingga sangat mungkin peserta didik memberikan output yang berbeda. Berdasarkan keterbatasan tersebut maka rekomendasi yang dapat penulis berikan bagi karya tulis selanjutnya yaitu adanya tulisan yang lebih komprehensif, yang mencoba melihat aplikasi model-model pendidikan perdamaian bagi anak dalam konteks gereja lokal di Indonesia.

\section{Kepustakaan}

Boehlke, Robert. Sejarah Perkembangan Pikiran dan Praktek Pendidikan Agama Kristen. Jakarta: BPK Gunung Mulia, 2009.

Durkheim, Emile. The Elementary Forms of The Religious Life. New York: The Free Press, 1915.

Fountain, Susan. "Peace Education in UNICEF", Working Paper of UNICEF New York (June 1999): 1, diakses 28 Agustus 2017, http://www.unicef.org/education/files/PeaceEducation.pdf. 
Freire, Paulo. Pedagogy of The Oppressed. New York: Continuum, 2005. . Education for Critical Conciousness. New York: Continuum, 2005. . Pedagogy of The Heart. New York: Continuum, 2000.

Grewal, Baljit singh. "Johan Galtung: Positive and Negative Peace," (Agustus 2003), diakses 1 November 2017, http://www.activeforpeace.org/no/fred/Positive_Negative_Peace.pd f.

Grome, Thomas. Christian Religious Education: Sharing Our Story and Vision. San Fransisco: Harper, 1980.

Harris, Ian dan John Synott. "Peace Education for a New Century", Social Alternatives 21, no.l (2002): 3-6.

Harris, Ian dan Mary Morrison. Peace Education: Third Edition. North Carolina: McFarland \& Company, Inc., Publishers, 2013.

Joyce, Bruce, dkk. Models of Teaching. Yogyakarta: Pustaka Pelajar, 2016.

McGinnis, Kathleen dan James. Parenting for Peace and Justice. New York: Orbis Books, 1982.

Mercer, Joyce. Welcoming Children: A Practical Theology of Childhood. Missouri: Chalice Press, 2005.

Nuhamara, Daniel. "Sistem Dominasi dan Resistensi Terhadapnya dalam Usaha Berteologi Sosial," Jurnal Studi Pembangunan Interdisiplin, vol. XX (2009): 273-284. . Pembimbing PAK. Bandung: Jurnal Info Media, 2007.

Page, James. Peace Education: Exploring Ethical and Philosophical Foundations. USA: Information Age Publisher, 2008.

Richards, Lawrence. Nurturing Faith within The Family of God. USA: The Zondervan Corporation, 1983.

Sumiyatiningsih, Dien. Mengajar dengan Kreatif dan Menarik. Yogyakarta: ANDI, 2006.

Tilahun, Temesgen. "Johan Galtung's Concept of Positive and Negative Peace in the Contemporary Ethiopia: an Appraisal," Academic Research Journal 3, no. 6 (Juni 2015): 251-258.

Westherhoff, John. Will Our Children Have Faith? New York: Seabury Press, 1976. 